Portland State University

PDXScholar

1971

\title{
Observations on the establishment of seedlings of Phoradendron californicum on Prosopis juliflora
}

Richard L. Null

Portland State University

Follow this and additional works at: https://pdxscholar.library.pdx.edu/open_access_etds

Part of the Botany Commons, Plant Biology Commons, and the Plant Pathology Commons Let us know how access to this document benefits you.

\section{Recommended Citation}

Null, Richard L., "Observations on the establishment of seedlings of Phoradendron californicum on Prosopis juliflora" (1971). Dissertations and Theses. Paper 1434.

https://doi.org/10.15760/etd.1433

This Thesis is brought to you for free and open access. It has been accepted for inclusion in Dissertations and Theses by an authorized administrator of PDXScholar. Please contact us if we can make this document more accessible: pdxscholar@pdx.edu. 
AN ABSTRACT OF THE THESIS OF Richard L. Null for the Master of Science in Biology presented July 30, 1971.

Title: Observations on the Establishment of Seedlings of Phoradendron californicum on Prosopis juliflora.

APPROVED BY MEMBERS OF THE THESIS COMMITTEE:

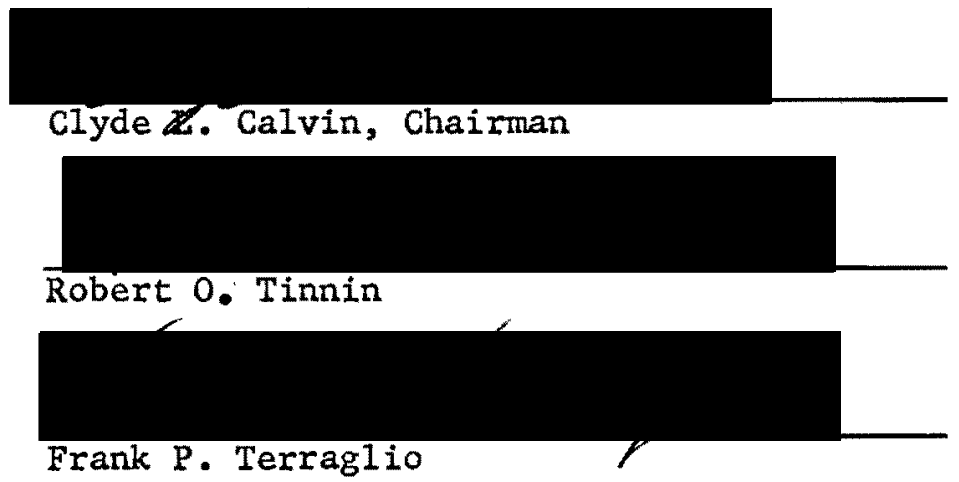

The mistletoe Phoradendron californicum is a common parasite on the mesquite plant Prosopis juliflora. Seeds of the parasite are deposited upon the host plant by birds and perhaps other agents. Normally seedlings of the parasite become established when the elongating radicle of the embryo comes into contact with a host branch and forms a holdfast. From the underside of the holdfast the primary haustorium enters the host tissue and establishes the parasitic union. Later the aerial portion of the parasite develops. Some seeds of $\mathrm{P}$. californicum follow a different sequence; they stimulate the host to produce gum in the tissue beneath the seed by apparent dissolution of cells. The exuded gum elevates the developing seed from the host branch preventing establishment of the hostparasite union. The possible significance of this apparent defense mechanism is discussed. 
Observations on the Establishment of Seedlings

of Phoradendron californicum on Prosopis juliflora

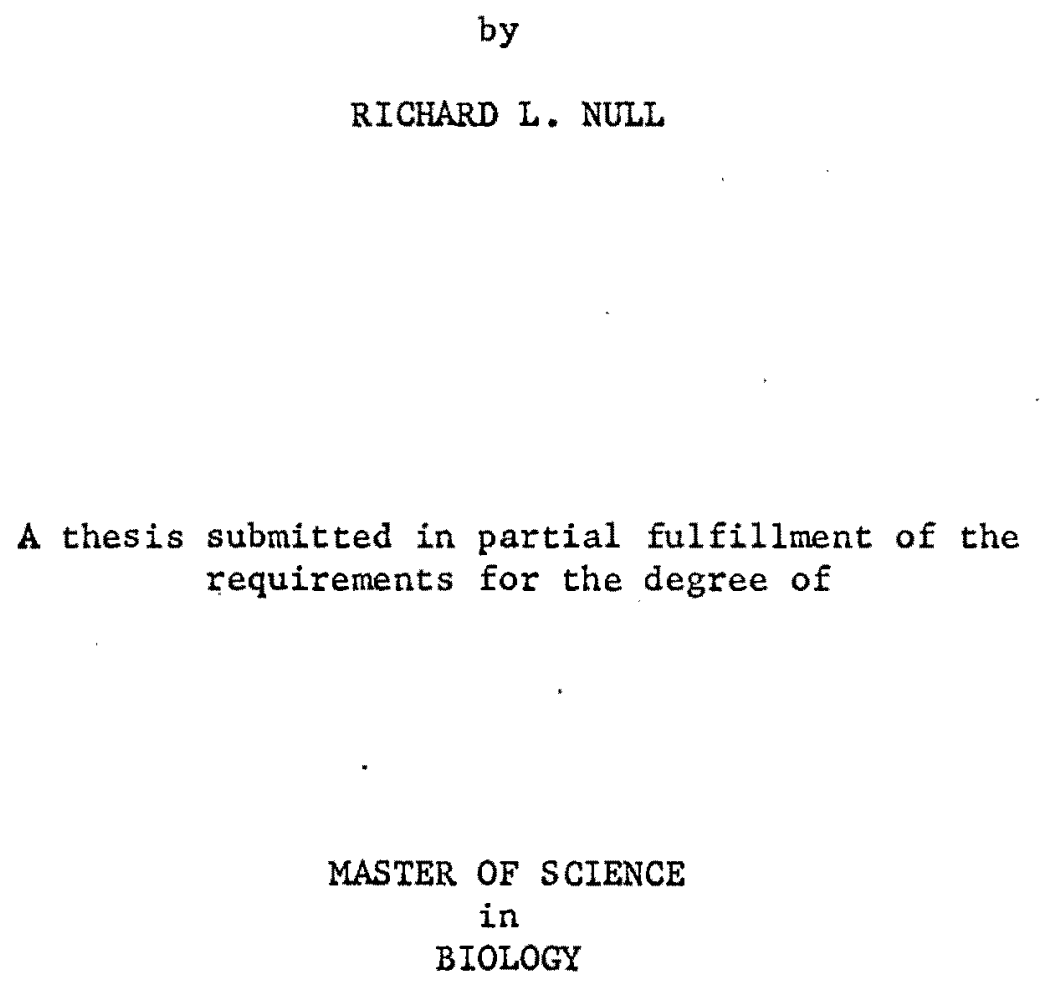

Portland State University

1971 
TO THE OFFICE OF GRADUATE STUDIES :

The members of the Committee approve the thesis of

R1chard I. Null presented July 30, 1971.

Clyde $\mathscr{~}$. Calvin, Chairman

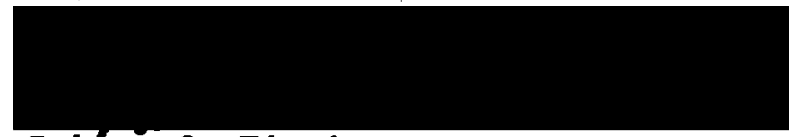

Robert 0. Tinnin

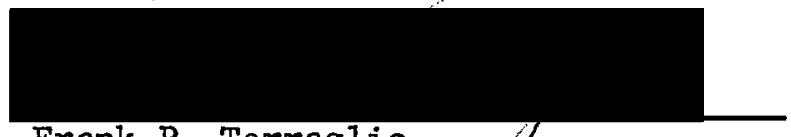

Frank P. Texraglio

APPROVED :

Earl Fisher, Jr., Head, Department of Biology

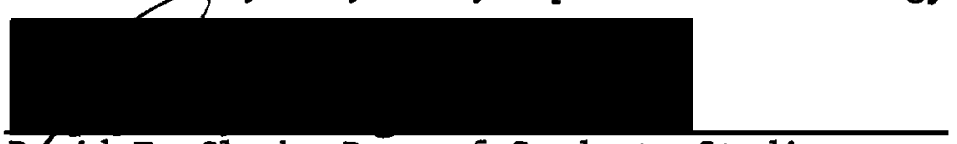

Dávid T. Clark, Dean of Graduate Studies

July 30,1971 
TABLE OF CONTENTS

PAGE

LIST OF TABLES ................... iv

LIST OF FIGURES. .................. v v

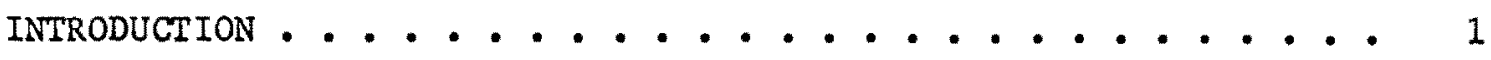

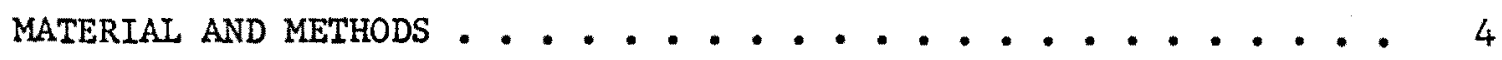

OBSERVATIONS ............................... 8

DISCUSSION . . . . . . . . . . . . . 13

IITERATURE CITED ............................ 15 
LIST OF TABLES

TABLE

PAGE

I Correlation Between the Association of Gum and Seeds . . . 9 
IIST OF FIGURES

FIGURES

PACE

1 Map of a portion of the Coachella Valley of California showing sites (1-5) where research material was collected; $1 \mathrm{~cm}=3.6 \mathrm{~km} . . . . . . . . . .$.

2 Portions of two mesquite hummocks; abundant mistletoe on mesquite plants at hummock to left; x $1 / 60 \ldots . . . .6$

3 Deposit of mistletoe seeds below bird perch; X 1/10. . 6

4 Several seeds on columns of gum; X 1.2........ 6

5 Enlarged view of one column of gum with germinated

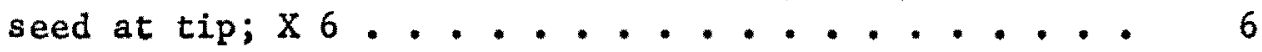

6 Enlarged view to show epidermis (at arrow) and subjacent tissue; $\mathrm{x} 4$.............. 6

$7 \quad$ View showing region covered by epidermis; "X 130 . . 11

8 Region where epidermis is absent; cuticle near left side at arrow; X 130 ............ 11

9 Break in continuity of epidermis; X 320....... 11

10 Break in continuity of epidermis; X 320 ....... 11

11 Region beneath mound of gum; cuticle at arrow; X 70. 11 


\section{INTRODUCTION}

Higher plants are attacked by many kinds of pathogens including viruses, bacteria, fungi, and parasitic vascular plants. In response to such attacks they have developed a wide range of defense mechanisms, both biochemical and structural (Agrios, 1969). Structural defense mechanisms can be categorized as preexisting or initiated in response to infection. The former category includes defense features dependent upon the epidermis. The latter includes the formation of cork and abscission layers, tyloses, and gums in response to irritation of the host by a pathogen.

of the numerous reports describing defense mechanisms operating In response to infection, few tell of host defense against parasitic vascular plants. However, Cowles (1936) has reported a particularly interesting reaction in which the host plant Prosopis juliflora (Sw.) DC. var. torrenyana L. Benson (mésquite) ${ }^{1}$ seemed to actively repel seeds of a parasitic vascular plant, Phoradendron californicum Nutt. (mistletoe).

Plants of Phoradendron californicum are frequently found growing on Prosopis juliflora. The dioecious mistletoe plants produce fragrant flowers in the spring and from these come small, reddish berries that can be found on the plant from late fall until spring. The berries serve as an important source of food for several birds (Cowles, 1936). In passing through the alimentary canal of the bird the berries lose

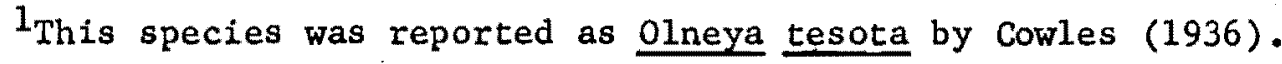


their outer covering and much of the viscous material (viscin) that lies between the seed and the covering. The viable, excreted portion consists of a massive endosperm with a partially embedded embryo surrounded by a somewhat scarious layer, and to the outside of this some viscous, adhesive material. After feeding, the birds commonly alight upon perches above their food source. Beneath the perches large deposits of excreted seeds accrue. Viable seeds are also found scattered along branches, in most cases deposited by birds.

Cowles (1936) observed that the germinated seeds of $\underline{P}$. californicum commonly sat upon columns of gum which had been exuded by the Prosopis juliflora, presumably in response to the presence of the parasite seeds. Once a germinating seedling was elevated beyond a certain point its radicle was unable to establish contact with the tissues of the host and the seedling subsequently perished. Cowles suggested that the mechanism offers the host some defense against parasitization. This phenomenon differs from the normal parasitization process of Phoradendron californicum where the seed sends out a radicle that, upon contact with host tissue, forms a holdfast. From the underside of the attached holdfast a haustorium, the primary haustorium, enters the host tissue and establishes the parasitic union. Subsequently, the visible, aerial portion develops.

I travelled to the Coachella Valley of California to a site having specimens exemplifying the phenomenon described by Cowles. The trip was made with two established goals: to quantify, in the time available, the extent and success of the mechanism described and to collect branches of Prosopis juliflora for study of the anatomical 
3

characteristics associated with the exudation of gum.

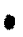


MATERIAL AND METHODS

Many stands of Prosopis Juliflora exist in the Coachella Valley. For the study five stands were chosen (1-5 in fig. 1) that showed a minimum of human disturbance. Four of the stands (nos. 1-4) were on the valley floor. Of these, three (nos. 1-3) were among active sand dunes, and the other was on sandy but stabilized soil. The fifth stand was at the base of the southwest facing slope of the Indio Hills. The soil at this location appeared less sandy than at the other sites and had crusted mineral deposits over its surface. The stands chosen were similar in that the $\underline{P}$. juliflora had numerous growths of $\underline{P}$. californicum (fig. 2) with abundant fruits, and bird perches (fig. 3). At each stand I searched for seeds or gum on the majority of the branches at the periphery of individual hummocks where the Prosopis juliflora was most vigorous. Al1 humnocks in stands three through five (about 15 hummocks in total) were examined.' At site one only three hummocks were examined and at site two, ten of the many hummocks present, were studied. During the examination most of the branches upon which seeds and/or gum were found were removed from the plant, labeled, and placed in plastic bags for later study. Care was taken to avoid knocking seeds from the branches. In the laboratory individual branches were examined for the number of seeds of $\underline{p}$. californicum directly associated (within $2 \mathrm{~mm}$ ) with the gum exudate and the number of gum mounds that were associated with seeds. The ages of several branches supporting seeds of the parasite were estimated by ring counts. 
Figure 1. Map of a portion of the Coachella Valley of California showing sites $(1-5)$ where research material was collected; $1 \mathrm{~cm}=$ $3.6 \mathrm{~km}$. 
(1)

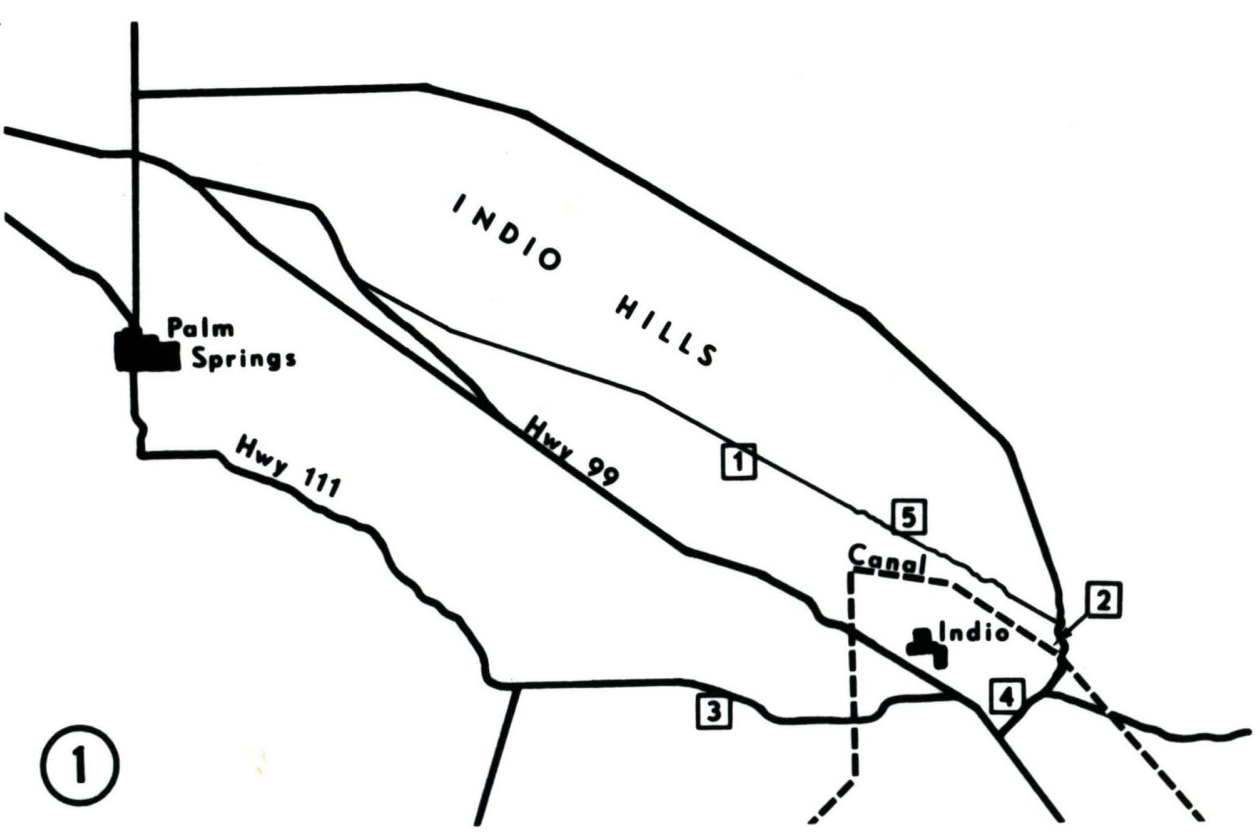


Figure 2-6. 2. Portions of two mesquite humocks; abundant mistletoe on mesquite plants at hummock to left, X 1/60. 3. Deposit of mistletoe seeds below bird perch, X 1/10. 4-6 branches of mesquite. 4. Several seeds on columns of gum, X 1.2. 5. Enlarged view of one column of gum with germinated seed at tip, X 6. 6. Enlarged view to show epidermis (at arrow) and subjacent tissue, X 4 . 


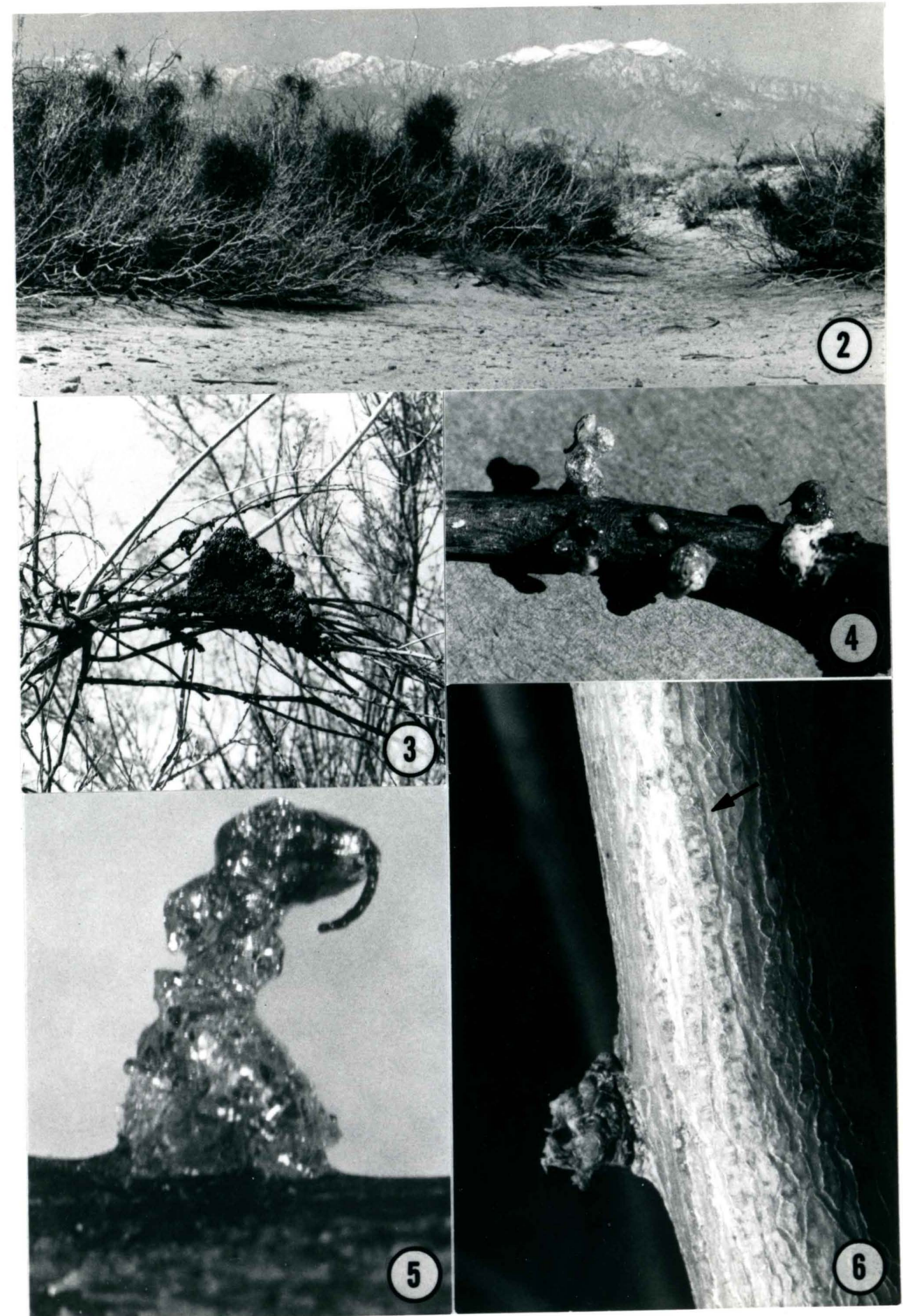


Segments showing different degrees of exudation of gum were re-. moved from some of the collected branches. The segments were fixed in formalin-propionic acid-alcohol. Subsequently this fixed material was dehydrated in tertiary butyl alcohol, embedded in paraffin (paraplast), and sectioned at $12 \mathrm{u}$. Most sections were stained, using tannic acidferric chloride-lacmoid (Cheadle, Gifford, and Esau, 1953), and mounted in Harleco synthetic resin. Some sections were left unstained for use in fluorescence microscopy. A Zeiss Standard Universal microscope was employed for microscopy, and for photography. 


\section{OBSERVATIONS}

The hummocks of Prosopis juliflora that were examined ranged in size from one to several meters in diameter (fig. 2). Typically they were circular with vigorously growing shoots at the periphery and poorly growing or dead branches to the interior. Whether this growth pattern was caused by a lowered water table or by a mechanism of autointoxication, comparable to that proposed by Muller (1966) to explain a similar growth pattern in Salvia lencophylla Greene, is unknown. Masses of seeds were found of Phoradendron californicum beneath bird perches (fig. 3), and others scattered along the Prosopis branches (fig. 4). Some of the scattered seeds had been elevated by a gum exudate (figs. 4, 5) as reported by Cowles (1936). This phenomenon occurred most frequently on branches with one to five growth rings. Since the area of branch surface which was covered by gum or seeds was quite small the probability of gum and seeds being juxtaposed by chance is minuscule. The findings (table 1 ) that $21 \%$ of the seeds were associated with gum and that $42 \%$ of the gum exudations were associated with seeds are much higher than would be expected by chance alone.

Study of the external morphology of Prosopis branches reveals that in younger regions the surface is homogeneous in appearance, and somewhat glossy due to the cuticle which covers the epidermal cells. On older branches the surface has a more irregular appearance (fig. 6). Glossy areas are still present (fig. 6, at arrow), but they form a mosaic pattern in conjunction with areas where subepidermal tissues are 
TABLE I

CORRELATION BETWEEN THE ASSOCLATION OF GUM AND SEEDS

\begin{tabular}{ccccc} 
Site no. & $\begin{array}{c}\text { No. of branches } \\
\text { collected }\end{array}$ & $\begin{array}{c}\text { No. of seeds } \\
\text { observed }\end{array}$ & $\begin{array}{c}\% \text { of seeds } \\
\text { associated } \\
\text { with gum }\end{array}$ & $\begin{array}{c}\% \text { of gum deposits } \\
\text { associated } \\
\text { with seeds }\end{array}$ \\
\hline 2 & 21 & 337 & 15 & $53(29 / 55)$ \\
3 & 34 & 333 & 39 & $41(60 / 147)$ \\
5 & 8 & 61 & 21 & $29(5 / 17)$ \\
Misc. & 12 & 142 & 10 & $45(9 / 20)$ \\
Mean & -2 & $-\ldots$ & 21 & $42(107 / 256)$
\end{tabular}

1. Actual number over tota1 number.

2. The miscellaneous category includes the combined data from sites one and four plus the data for branches accidentally separated from their labels during transit. 
exposed. The Phoradendron californicum seeds that come to rest on a Prosopis branch normally are in contact with both epidermal and subepidermal tissues.

Figure 7 illustrates a cross section of a branch comparable in age to that seen in figure 6 . Here the tissues of the stem are delimited externally by a thick but barely visible cuticle, corresponding to an area like that indicated by the arrow in figure 6 . Other features are also evident, including in a centripetal direction: (1) tangentially elongated epidermal cells; (2) a cork layer comprised of cells in the characteristic radial files, and presumably arising from one of the outermost cortical layers (Metcalfe and Chalk, 1950); (3) cortical parenchyma cells; (4) a several-celled layer of thick-walled cells made up of groups of primary phloem fibers alternating with groups of sclereids; and, (5) layers of secondary phloem fibers alternating with layers comprised of living parenchyma cells and obliterated phloem elements.

An area of the stem where subepidermal tissues are exposed is shown in figure 8. The original epidermis is not visible except near the left edge of the figure (at arrow). The surface is covered by the cork layer throughout most of its extent. However, a break in the continuity of the cork layer is evident near the center of the figure. In this area thin-walled parenchymatous cells are exposed directly to the external environment. The areas of the type illustrated in figure 8 appear at an earlier stage as small breaks which interrupt the continuity of the epidermis (figs. 9, 10). Whether the breaks precede or are a result of activity in the cork layer (fig. 9) was not determined with 
Figure 7-11. Cross sections of stem as seen using ordinary (Figs. 7-9, 11) and fluorescence (Fig. 10) microscopy. 7. View showing region covered by epidermis, X 130. 8. Region where epidermis is absent; cuticle near left side at arrow, X 130. 9, 10. Break in continuity of epidermis, X 320. 11. Region beneath mound of gum; cuticle at arrow, $\mathrm{X} 70$. 


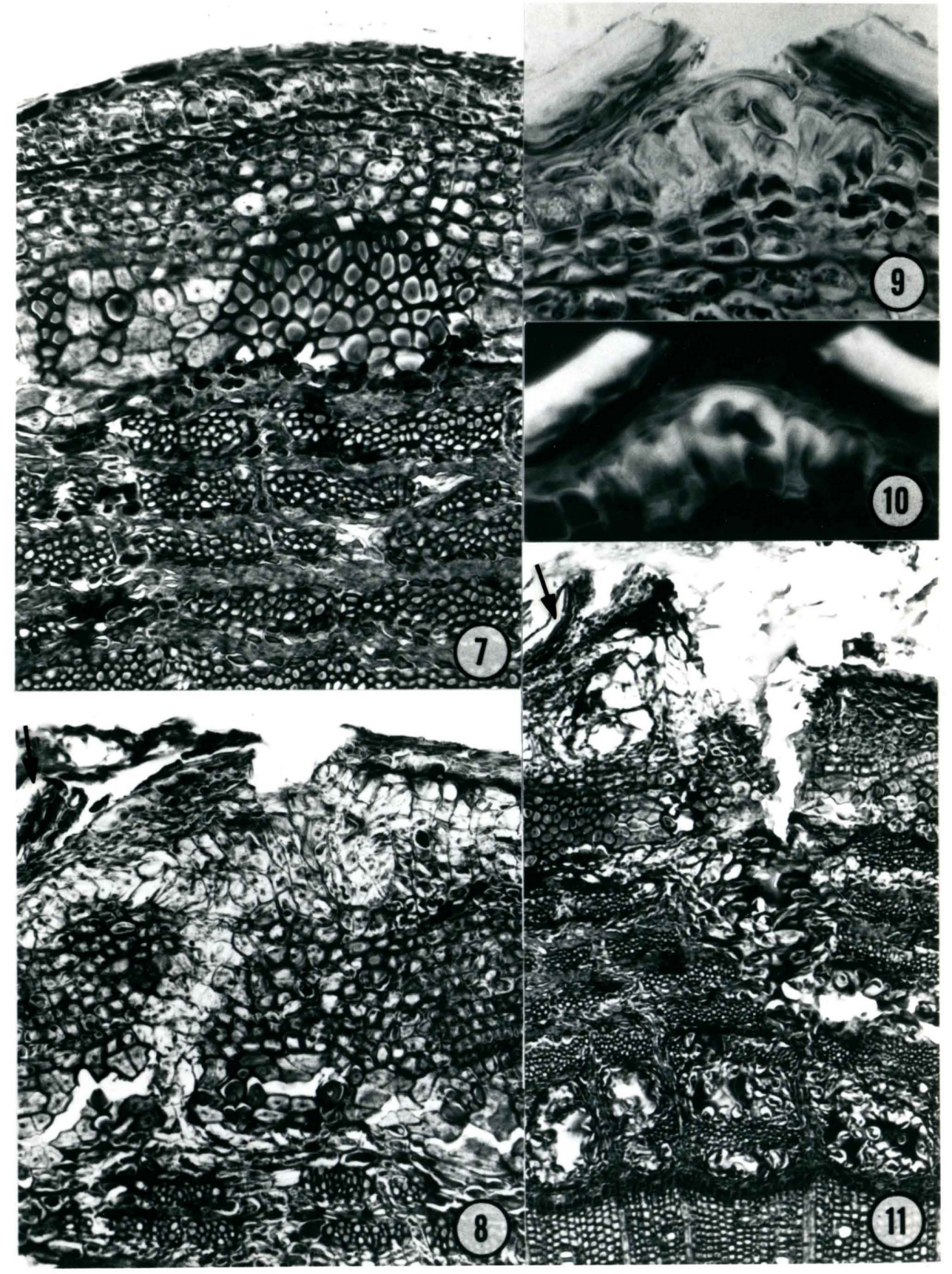


certainty. In any event the newly exposed cells are associated with a protective covering of lipoidal nature, as were the epidermal cells (fig. 10). Another feature illustrated in figure 8 is the presence of thin-walled parenchyma cells not only near the surface of the branch but also extending inward across the cortex and sclerenchyma tissues. To the inside of the sclerenchyma layer the parenchyma cells are conmonly continuous with the cells of the phloem rays.

A segment of the stem taken from beneath a mound of gum is illustrated in figure 11. Prior to gum formation the region presumably looked similar to that illustrated in figure 8 . The region is now characterized by an apparent dissolution of many living cells not only near the surface, but also extending inward across the cortex, sclerenchyma sheath, and into the secondary phloem. In the phloem the cell dissolution is most noticeable in the wider, dilated ray and in the functional phloem. Cells in the xylem did not show any dissolution, but some contained deposits of gums and appeared similar to those illustrated by Esau (1948) for plants infected with certain viruses. 


\section{DISCUSSION}

Gums are a common though poorly understood group of chemical constituents of higher plants. They are hydrophilic polysaccharides (Langenheim, 1969) that are either soluble in water or swell to a jelly-like mass, but they remain insoluble in organic solvents (Howes, 1949). It appears that the presence of gums in plants is mainly a result of physiological or pathological disturbances that induce a breakdown of cell walls and cell contents, particularly starch (Esau, 1965).

There is little doubt that the exudation of certain gums by Prosopis juliflora is related to the presence on the branches of seeds of Phoradendron californicum. This is evidenced by the high correlation of association between the gum mounds and the seeds. Had it not been for the presence of freshly deposited seeds being included in the calculations, and for the effects of rain falling in the study area shortly before my arrival (thereby washing seeds from mounds and dissolving some gum deposits) the correlation would have been even higher. The mistletoe seeds deposited upon branches could stimulate the production of gum either by physiological (i.e., secretion of chemical compounds, restriction of the oxygen supply, etc.) or pathological (i.e., introduction of pathogenic organisms) disturbance of the host tissue. The anatomical observations illustrated that on the younger branches seeds may be in contact more or less directly with the internal tissues of the stem. These tissues, comprised in part of thin-walled 
parenchyma cells, are present not only beneath the seed, but extend across the cortex, sclerenchyma sheath, and are continuous with the tissues of the secondary phloem (fig. 8). The dissolution of these and adjacent (fig. 11) cells apparently leads to the formation of gum. The gum thus formed has a more or less direct pathway to the outside of the stem, its passage is blocked only by the mistletoe seeds. As the gum exudes from the stem it elevates the seeds (fig. 5) as already described. Whether the elevation of mistletoe seeds by the exudation of gum is an actual or potential mechanism against parasitization, or merely a botanical accident, is problematic. The presence of numerous--but mostly older--infections of Phoradendron californicum on the Prosopis juliflora studied illustrates that the infection process can and does occur. It may be that under the apparent stress conditions, to which much of the Prosopis appears to be subjected, the expulsion of seeds is a common phenomenon. It has been found in Acacia senegal, the source of the best gum arabic, that plants do not yield gum when in a state of active healthy growth with an abundance of soil moisture and soil nutrients, but do when in a state of poor vigor (Howes, 1949). If the elevation of the parasite seeds is tied to the irritation of a host plant growing under unfavorable conditions then the resistance aspect is secondary. A similar response, gum production, may occur as a result of penetration of an insect stylet or application of a few drops of a dilute acid. On the other hand, the defense mechanism per se may be related directly to natural selection. Then, depending upon the intensity of the selective pressures associated with the parasitization of Prosopis juliflora, the mechanism has the potential to be refined through time into an efficient defense against infection by Phoradendron californicum. 
Agrios, G. N. 1969. Plant Pathology. Academic Press, New York.

Cheadle, V. I.; Gifford, Jr., E.M. and Esau, Katherine. 1953. A staining combination for phloem and contiguous tissues. Stain Techno1. 28:49-53.

Cowles, R.B. 1936. The relation of birds to seed dispersal of the desert mistletoe. Madrono 3:352-356.

Esau, Katherine. 1948. Anatomic effects of the viruses of Pierce's disease and phony peach. Hilgardia 18:423-482.

1965. Plant Anatomy. Wiley, New York.

Howes, F. N. 1949. Vegetable Gums and Resins. Chronica Botanica, Waltham, Massachusetts.

Langenheim, J. H. 1969. Amber: a botanical inquiry. Science 163: 1157-1169.

Metcalfe, C. R. and Chalk, L. 1950. Anatomy of the Dicotyledons. Clarendon Press, Oxford.

Muller, C. H. 1966. The role of chemical inhibition (allelopathy) in vegetational composition. Bull. Torr. Bot. Club 93:332-351. 